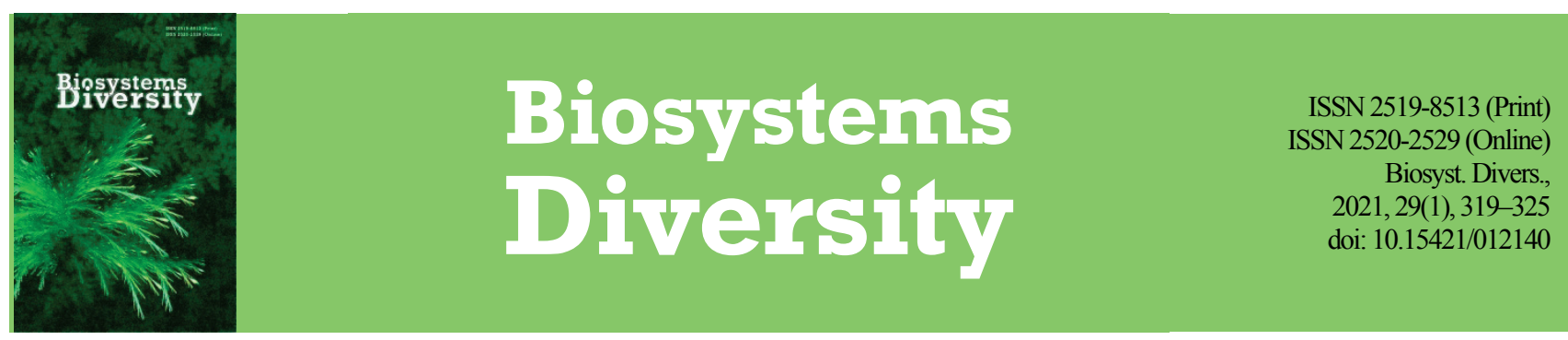

\title{
Assessment of soil quality in agroecosystems based on soil fauna
}

\author{
V. Langraf*, K. Petrovičová**, J. Schlarmannová*, S. David*, T. A. Avtaeva***, V. V. Brygadyrenko**** \\ *Constantine the Philosopher University in Nitra, Nitra, Slovak Republic \\ **University of Agriculture in Nitra, Nitra, Slovak Republic \\ ***Chechen State Pedagogical University, Grozny, Russia \\ ****Oles Honchar Dnipro National University, Dnipro, Ukraine
}

Article info: Received 04.11.2021

Received in revised form 26.11 .2021

Accepted 28.11.2021

Constantine the Philosopher University in Nitra,

Tr. A. Hlinku, 1, Nitra, 94901, Slovak Republic.

E-mail:langrafiladimir@gmail.com

University of Agriculture in Nitra, Tr. A. Hlinku, 2, Nitra, 94901, Slovak Republic.

E-mail:kornelia.petrovicova@gmail.com

Chechen State Pedagogical University, Subry Kishievoyst., 33, Grozny, 364068, Chechen Republic, Russia.E-mail:avtaeva1971@mail.ru

Oles Honchar Dnipro National University, Gagarin av. 72, Dnipro, 49010, Ukraine. Tel.:+38-050-93-90-788. E-mail: brigad@ua.fm

\section{Introduction}

Soil is one of the most species-rich habitats, representing the decomposition subsystem of terrestrial ecosystems. It reflects ecosystem quality, where all bio-geo-chemical processes of soil and different ecosystem components are combined. A criterion of evaluating long-term sustainability of ecosystems is to assess the fluctuations of soil quality (Schoenholtz et al., 2000). Regarding soil quality indicators, there is a heavy reliance upon a few appraisals such as soil organic matter among chemical indicators (Gilley et al., 2001), bulk density (Li et al., 2001) and aggregate stability (Six et al., 2000). Biological monitoring is required to correctly assess soil degradation and correlated risks. There is a need to identify indicators which are capable of expressing soil quality criteria and can be used as bench-marks in environmental remediation, as well as to assess and monitor soil quality (Violante, 2000).

Soil fauna is considered to be an important component of the soil ecosystem for maintaining nutrient cycling and soil fertility (Osler \& Sommerkorn, 2007). It is considered to be a useful indicator of soil quality because it is sensitive to changes in land management (Yeates, 2003). As indicators of soil quality, the abundance and diversity of soil fauna integrate the physical, chemical, microbiological properties of soil, and reflect general ecological change (Menta et al., 2008).

The application of biological indicators is limited by the difficulties in identifying species of soil arthropods. A simplified eco-morphological index (EMI) based on the types of soil microarthropods, does not require species level identification (Parisi \& Menta, 2008). The EMI index was used to evaluate soil quality using the Qualità Biologica del Suolo (QBS index). The QBS index is based on the arthropod groups present in a soil sample and does not include any measure of abundance. It follows that soil arthropods with the same EMIs have the same effect on the ecosystem when their true effects could differ because of differences in abundance. Soil quality is positively correlated with the number of arthropod groups that are well-adapted to soil habitats. The
QBS index is a measure of how well the soil fauna adapts to the particular soil (Aspetti et al., 2010). Soil invertebrates need the energy obtained from the microbial degradation of organic matter in order to make a positive effect on the nutrient recycling processes (Potapov et al., 2017; Lajtha et al., 2018). They are important in supporting and regulating ecosystem services (Lavelle et al., 2006). Organic matter forming waste represents the basis of a detritus based food web whose primary consumers are bacteria and fungi.

The microbial feeders, saprovores and secondary consumers such as nematodes, oribatid mites and proturans are the most abundant organisms of the soil fauna. Arachnids, predaceous mites, pseudoscorpions, small spiders and centipedes are at the higher trophic levels (Brygadyrenko \& Reshetniak, 2014; Ruchin et al., 2018, 2021). In moist soils rich in organic matter, the total density of soil arthropods can be hundreds of thousands of specimens $/ \mathrm{m}^{2}$ (Coleman \& Wall, 2015; Orgiazzi et al., 2016; Menta \& Remelli, 2020). The biocenosis of soil depends on the organic matter such as undecayed plant and animal residues and its role is the degradation of such matter in order to make mineral nutrients available (N, P, K) to plants (Wardle, 2002; Murphy, 2014). This cycle is linked to the sequestration of a large amount of carbon and, therefore, soil management and conservation can be considered of global interest from many points of view, from the regulation of climate processes to the productivity of agroecosystems. The intensity of land use is also affected by working with the plough. The rate of natural setting of the soil after ploughing depends on the structure, fragmentation and amount of precipitation. Therefore, ploughing ensures favourable conditions and supports the activity of soil arthropods (Lal, 2004; Lajtha et al., 2018; Ondrasek et al., 2019).

The aim of this paper is to evaluate soil quality, based on QBS index in crops grass mixture, Pisum sativum, Triticum aestivum, T. spelta, Brassica napus, Zea mays, Hordeum vulgare. It was also intended to discover the influence of environmental variables (soil moisture, soil $\mathrm{pH}$, potassium, phosphorus and nitrogen) on the EMI index. 


\section{Materials and methods}

The research took place during the years 2018 to 2020, during which we collected soil arthropods from seven types of agricultural crops. These types of agricultural crops were examined throughout each year, the position of crops in the fields changed every year. The fields of the individual crops were adjacent to each other (Fig. 1).

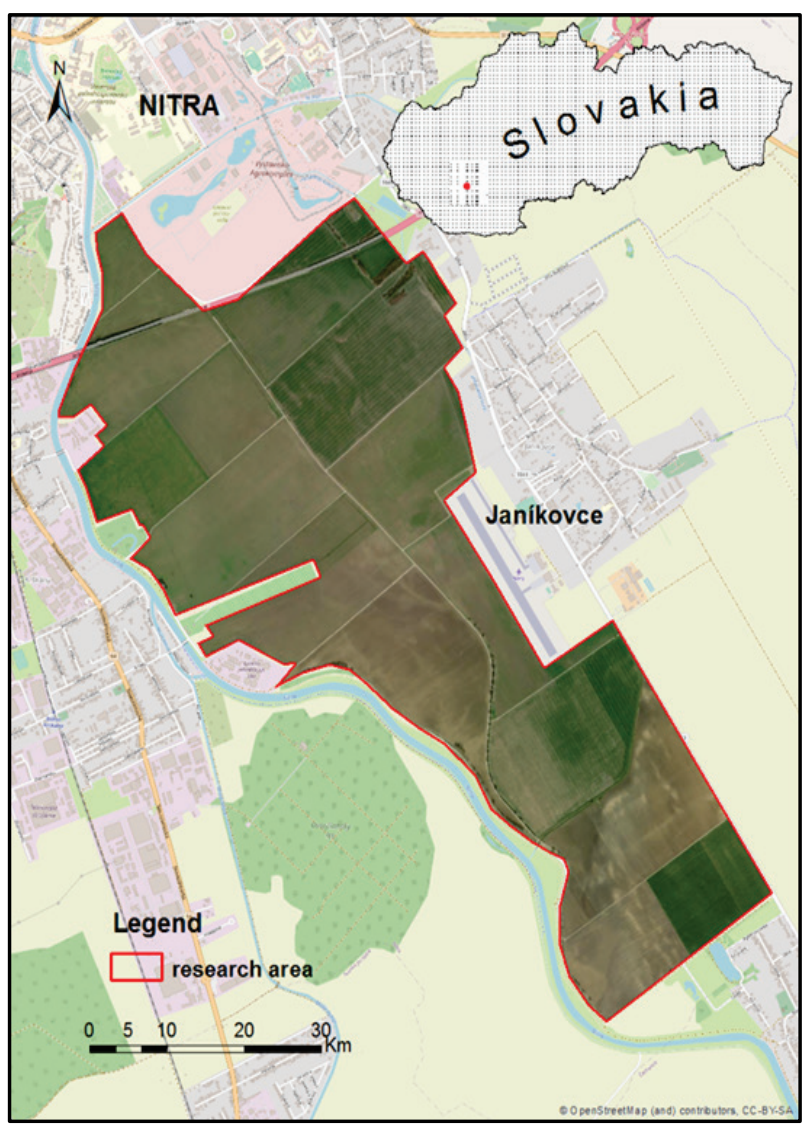

Fig. 1. Map of the study area

In winter-planted crops (Brassica napus, Pisum sativum, Triticum aestivum, T. spelta), soil arthropods were collected from November to July. In the spring-planted crops (Zea mays, Hordeum vulgare), soil arthropods were trapped from April to October. In the grass mixture, soil arthropods were collected all year round. For crops conventional tillage was applied based on annual tillage ploughing, incorporating crop residues and weeds into the soil. The soil was ploughed three times and turned. Presowing preparation and sowing were combined. Machines with driven working tools were used in conjunction with a seed drill. When sowing, it was possible to use seed coulters with an obtuse angle of penetration into the soil. The study area was located in the Podunajská pahorkatinaDanubian upland geomorphological unit (South-Western Slovakia) in the cadastral territory of Nitra. The altitude of the monitored area was approximately $130 \mathrm{~m}$ above sea level with a brown soil type. The study area is considered a warm arid climate with mild winters. The mean temperature ranges during each month were as follows: January $-5-5^{\circ} \mathrm{C}$, February $-3-6{ }^{\circ} \mathrm{C}$, March $0-12{ }^{\circ} \mathrm{C}$, April $10-20{ }^{\circ} \mathrm{C}$, May $15-22{ }^{\circ} \mathrm{C}$, June 18 $27^{\circ} \mathrm{C}$, July $22-29^{\circ} \mathrm{C}$, August $20-29^{\circ} \mathrm{C}$, September $15-23^{\circ} \mathrm{C}$, October $8-15^{\circ} \mathrm{C}$, November $-3-7^{\circ} \mathrm{C}$, December $-5-5^{\circ} \mathrm{C}$. The average precipitation for each month was as follows: January $30 \mathrm{~mm}$, February $26 \mathrm{~mm}$, March $35 \mathrm{~mm}$, April $12 \mathrm{~mm}$, May $65 \mathrm{~mm}$, June $77 \mathrm{~mm}$, July $41 \mathrm{~mm}$, August $57 \mathrm{~mm}$, September $64 \mathrm{~mm}$, October $54 \mathrm{~mm}$, November $40 \mathrm{~mm}$ and December $55 \mathrm{~mm}$. Each field was sampled ten times for one year during the monitoring period (years 2018, 2019, 2020). Each time, five replicates of soil cores $(10 \times 10 \times 10 \mathrm{~cm})$ were collected from each field, following a linear path at a distance of $20 \mathrm{~m}$ between every soil cores. Soil samples were collected regularly in two-week intervals every year (2018 to 2020). Arthropod extraction was performed by Berlese-Tüllgren funnel for 10 days. The extracted specimens were collected and preserved in $75 \%$ ethyl alcohol and $25 \%$ glycerol by volume. The nomenclature of soil arthropods was established according to the works of Majzlan (2009), Pokorný \& Šifner (2004).

The insecticide FORCE (Syngenta, Basel, Switzerland), a granular insecticide intended for soil application to control soil pests, was applied to the crops (Brassica napus, Zea mays, Hordeum vulgare). Insects were killed through respiratory and tactile poison ingestion. The preparation had a fast effect and a strong residual (repellent) action against a wide range of soil pests from the orders of Coleoptera, Aranea and Hymenoptera. The applied dose was administered uniformly at a concentration of 12 $15 \mathrm{~kg}$ per ha each year for the duration of the research. Solinure FX fertilizer (Medilco Hellas S.A., Athens, Greece) containing chlorides and urea, was applied to the crops and was intended for field fertility. Due to its acidifying effect, it contributed to lowering the soil $\mathrm{pH}$.

At each pitfall trap location we removed stones, fallen leaves from crops and sampled the soil to a depth of $15 \mathrm{~cm}$ for analysis. Samples were taken from each field every two weeks over a period of three years. Subsequently, environmental variables $(\mathrm{N}, \mathrm{P}, \mathrm{K}, \mathrm{pH}$, soil and moisture) were analyzed using soil moisture meter (Rapitest 3 1835, Luster Leaf, Illinois, USA) and $\mathrm{pH}$ meter (Dexxer (PH-03, Luboň Poland). We thoroughly wet the broken-up soil with water (ideally distilled or deionized water) to a mud consistency. We wiped the meter probe clean with a tissue or paper towel. The probe was inserted into the soil up to the probe base $(7-10 \mathrm{~cm})$. We waited one minute and wrote the value. We converted the measured values into units of $\mathrm{mg}$. The average values of environmental variables for all crops during the years 2018-2020 are shown in Table 1.

Table 1

Average values of environmental variables during 2018-2020 for the studied crops

\begin{tabular}{lccccc}
\hline \multicolumn{1}{c}{ Crops } & $\mathrm{pH}$ & $\begin{array}{c}\text { Nitrogen, } \\
\mathrm{mg}\end{array}$ & $\begin{array}{c}\text { Phospho- } \\
\mathrm{rus}, \mathrm{mg}\end{array}$ & $\begin{array}{c}\text { Potassi- } \\
\mathrm{um}, \mathrm{mg}\end{array}$ & $\begin{array}{c}\text { Moisture, } \\
\%\end{array}$ \\
\hline Grass mixture & 6.73 & 13.11 & 1.05 & 13.11 & 32.69 \\
Pisum sativum & 6.90 & 9.81 & 0.78 & 9.81 & 27.77 \\
Hordeum vulgare & 6.84 & 15.69 & 1.26 & 15.69 & 37.13 \\
Zea mays & 6.66 & 12.72 & 1.02 & 12.72 & 32.66 \\
Triticum aestivum & 6.98 & 21.84 & 1.75 & 21.84 & 41.89 \\
Brassica napus & 7.06 & 13.52 & 1.08 & 13.52 & 39.75 \\
Triticum spelta & 6.89 & 12.93 & 1.03 & 12.93 & 28.29 \\
\hline
\end{tabular}

The data obtained by the research has been saved in the Microsoft SQL Server 2017 database program (Express Edition), consisting of frequency tables for collections and measured environmental variables $(\mathrm{pH}$, soil moisture, potassium, phosphorus and nitrogen). The database also consisted of code tables for study sites and their variables (crops, habitat, locality name, cadastral area, altitude and coordinates of localities). Matrices for statistical calculations using (Microsoft SQL Server 2017; (RTM) 14.0.1000.169 (X64) 2017 Microsoft Corporation Express Edition (64bit) on Windows 10 Home 10.0) were programmed.

Multivariate analysis (redundancy analysis - RDA) to determine the dependencies between objects (soil arthropods and crops, soil variables) was used. We tested the statistical significance of crops (Brassica napus, Pisum sativum, Triticum aestivum, T. spelta, Zea mays, grass mixture, Hordeum vulgare) and soil variables (moisture, $\mathrm{pH}$, phosphorus, potassium and nitrogen) using the Monte Carlo permutation test (iterations = 499) in the Canoco5 program (Ter Braak \& Šmilauer, 2012; Canoco reference manual and user's guide: software for ordination, version 5.0; Ithaca USA: Microcomputer Power).

Analysis in the statistical program Statistica (Statsoft, 2004) focused on linear regression, expressing the relationship between the value EMI of soil arthropods and the values of potassium, phosphorus, nitrogen, $\mathrm{pH}$ and soil moisture was used.

The biological forms present in a sample were divided into the different adaptation levels of soil environment for every systematic group. For each higher taxon, the QBS method requires searching for the biological form (morphotype) that is most adapted to soil. As a general rule, euedaphic (i.e. deep soil-living) forms get an EMI $=20$, hemiedaphic (i.e. intermediate) forms are given an index rating proportionate to their degree of specialization, while epiedaphic (surface-living) forms score 
$\mathrm{EMI}=1 . \mathrm{EMI}$ values for taxa are given in (Parisi et al., 2005). If two ecomorphological forms are present in the same taxa group, the final score is determined by the higher EMI. To calculate the QBS score of fields, it is sufficient to sum up the EMIs of all collected groups.

\section{Results}

A total of 27,943 specimens belonging to 14 taxa were observed. Taxa of Coleoptera (46\%), Collembola (18\%) and Diplopoda (13\%) had an eudominant representation of specimens. Araneae $(6 \%)$ were dominant, the other groups had subdominant to subrecendent representation. Fields with grass mixture, Pisum sativum, Triticum aestivum, T. spelta had a high QBS value. Fields with Zea mays, grass mixture, Hordeum vulgare had a low value (Table 2).

Multivariate analysis of the soil arthropods between the years 2018 and 2020 was determined using the redundancy analysis (RDA, SD (length of gradient) is 1.80 on the first ordination axis). We observed the relationship between soil arthropods and crops (grass mixture, Pisum sativum, Triticum aestivum, T. spelta, Brassica napus, Zea mays, Hordeum vulgare). The values of the explained cumulative variability of taxonomic data were $48.6 \%$ on the first ordination axis and $53.1 \%$ on the second ordination axis. The cumulative variability of the species set explained by crops was represented in the first ordination axis at $78.8 \%$ and in the 2 nd axis at $90.9 \%$. Using the Monte Carlo permutation test, we identified a statistically significant effect of grass mixture $\left(\mathrm{P}=0.046, \mathrm{~F}_{(1.393)}=2.052\right.$, $\mathrm{df}=6)$, Pisum sativum $\left(\mathrm{P}=0.014, \mathrm{~F}_{(1.623)}=1.911, \mathrm{df}=6\right)$, Triticum aestivum $\left(\mathrm{P}=0.021, \mathrm{~F}_{(2.212)}=3.102, \mathrm{df}=6\right)$, Triticum spelta $(\mathrm{P}=0.042$, $\left.\mathrm{F}_{(3.112)}=4.212, \mathrm{df}=6\right)$, Hordeum vulgare $\left(\mathrm{P}=0.045, \mathrm{~F}_{(1.139)}=1.527, \mathrm{df}=\right.$ 6 ) on the structure of soil arthropods. No significant effect was found for Brassica napus $\left(\mathrm{P}=0.156, \mathrm{~F}_{(3.937)}=1.452, \mathrm{df}=6\right)$, Zea mays $(\mathrm{P}=0.394$, $\left.\mathrm{F}_{(2.184)}=1.974, \mathrm{df}=6\right)$ on the structure of soil arthropods. The selected variables were not mutually correlated with the maximum value of the inflation factor 1.714. The ordination graph (biplot) had a predominance of soil arthropods ordered around the crops grass mixture, Pisum sativum, Triticum aestivum, T. spelta (cluster I). The second cluster (II) was represented by taxa linking to Hordeum vulgare. The third cluster (III) consisted of soil arthropods with a preference for Brassica napus, Zea mays (Fig. 2).

Table 2

Soil arthropod taxa, associated EMI, QBS values and number of individuals for crops

\begin{tabular}{|c|c|c|c|c|c|c|c|c|c|c|c|c|c|c|}
\hline \multirow{2}{*}{ Taxa } & \multicolumn{2}{|c|}{ Grass mixture } & \multicolumn{2}{|c|}{ Pisum sativum } & \multicolumn{2}{|c|}{ Triticum aestivum } & \multicolumn{2}{|c|}{ Triticum spelta } & \multicolumn{2}{|c|}{ Hordeum vulgare } & \multicolumn{2}{|c|}{ Zea mays } & \multicolumn{2}{|c|}{ Brassica napus } \\
\hline & EMI & ind. & EMI & ind. & EMI & ind. & EMI & ind. & EMI & ind. & EMI & ind. & EMI & ind. \\
\hline Collembola & 4 & 374 & - & - & 4 & - & 4 & - & 4 & 126 & 4 & - & - & - \\
\hline Dermaptera & 1 & 1189 & 1 & 83 & 1 & 11 & - & 34 & - & 309 & 1 & 74 & - & 67 \\
\hline Orthoptera & 20 & 2835 & 20 & 505 & 20 & 463 & 20 & 401 & 20 & 2738 & 20 & 5263 & 20 & 539 \\
\hline Hemiptera & 1 & 3814 & - & - & 1 & - & 1 & - & 1 & 1539 & - & 2 & 1 & - \\
\hline Coleoptera & 6 & 1 & 6 & 39 & 6 & 27 & 6 & - & 6 & - & 6 & 1 & 6 & - \\
\hline Hymenoptera & 5 & 3109 & 5 & 92 & 5 & 167 & 5 & 4 & 5 & 66 & 5 & 42 & 5 & 4 \\
\hline Diptera (larvae) & 10 & 519 & 10 & 1 & 10 & 45 & 10 & - & - & 494 & 10 & 126 & 10 & 13 \\
\hline $\begin{array}{l}\text { Other holometabolous } \\
\text { insects (adults) }\end{array}$ & 1 & 148 & - & - & - & - & - & - & - & 65 & - & - & - & 2 \\
\hline Acari & 20 & 277 & 20 & 32 & 20 & 18 & 20 & 5 & 20 & 695 & - & 53 & - & 25 \\
\hline Araneae & 5 & 61 & 5 & - & 5 & - & 5 & - & 5 & 14 & 5 & 72 & 5 & 3 \\
\hline Opiliones & 10 & 146 & 10 & 30 & 10 & 1 & 10 & 31 & 10 & 5 & 10 & 447 & - & 4 \\
\hline Isopoda & 10 & 40 & 10 & - & 10 & - & 10 & - & 10 & 21 & 10 & 85 & 10 & - \\
\hline Chilopoda & 20 & 290 & 20 & 27 & 20 & 53 & 20 & 6 & 20 & 36 & 20 & 90 & 20 & 39 \\
\hline Diplopoda & 5 & 5 & 5 & - & 5 & - & 5 & - & 5 & - & 5 & - & 5 & - \\
\hline $\begin{array}{l}\text { QBS index/ } \\
\sum \text { individuals }\end{array}$ & 118 & 12809 & 112 & 809 & 117 & 785 & 116 & 481 & 106 & 6108 & 96 & 6256 & 82 & 695 \\
\hline
\end{tabular}

Note: ind. - individuals.

In the second stage of multivariate analysis using redundancy analysis (RDA, SD (length of gradient) is 1.80 on the first ordination axis), we observed relationships between soil arthropod groups and soil variables ( $\mathrm{pH}$ of the soil, soil moisture, potassium, phosphorus, nitrogen). The values of the explained variability in taxonomic data were $48.6 \%$ on the first ordination axis and $53.1 \%$ on the second ordination axis. The cumulative variability of the set of taxa explained by soil variables was on the first ordination axis $86.4 \%$ and on the second axis $94.5 \%$. Using the Monte Carlo permutation test, we identified a statistically significant effect of soil moisture $\left(\mathrm{P}=0.004, \mathrm{~F}_{(1.221)}=1.451, \mathrm{df}=3\right), \mathrm{pH}$ of soil $\left(\mathrm{P}=0.018, \mathrm{~F}_{(1.714)}=\right.$ 1.899, $\mathrm{df}=3)$, phosphorus $\left(\mathrm{P}=0.032, \mathrm{~F}_{(1.112)}=1.392, \mathrm{df}=3\right)$, potassium $\left(\mathrm{P}=0.026, \mathrm{~F}_{(1.368)}=1.911, \mathrm{df}=3\right)$ and nitrogen $\left(\mathrm{P}=0.016, \mathrm{~F}_{(1.614)}=2.045\right.$, $\mathrm{df}=3$ ) on the structure of soil arthropods. The selected variables were not mutually correlated with the maximum value of the inflation factor 1.6266. The ordination graph (biplot) contained of taxa ordered into two clusters (Fig. 3). The first cluster (I) consisted of soil arthropods correlated with phosphorus (mg), nitrogen (mg) and potassium (mg). The second cluster (II) was represented by taxa linking to $\mathrm{pH}$ and moisture (\%).

The values of EMI of taxa were processed using linear regression. Using the regression model, we expressed the relationship (correlation) between values of EMI and potassium $(\mathrm{mg} / \mathrm{kg})$, phosphorus $(\mathrm{mg} / \mathrm{kg})$, nitrogen $(\mathrm{mg} / \mathrm{kg}), \mathrm{pH}$ and humidity $(\%)$. The correlation coefficient value was high for the values EMI of taxa and moisture ( $\%, r=0.851$, Fig. $4 \mathrm{~A})$, potassium $(r=0.741$, Fig. $4 B)$, phosphorus $(r=0.731$, Fig. $4 \mathrm{C})$, nitrogen $(\mathrm{r}=0.891$, Fig. 4D) and $\mathrm{pH}(\mathrm{r}=0.711$, Fig. 4F), which indicated a strong relationship. The reliability coefficient for moisture $R^{2}=0.781$ indicated the capture of $78.1 \%$ variability, potassium $\mathrm{R}^{2}=0.712$, phosphorus $\mathrm{R}^{2}=$ 0.851 , nitrogen $\mathrm{R}^{2}=0.791$ and $\mathrm{pH} \mathrm{R}^{2}=0.711$. The overall suitability of the regression model is statistically significant in all cases: moisture $(\mathrm{P}=$ 0.038), potassium ( $P=0.048)$, phosphorus $(\mathrm{P}=0.047)$, nitrogen $(\mathrm{P}=$
$0.039)$ and $\mathrm{pH}(\mathrm{P}=0.037)$. The results showed that increasing values of potassium, phosphorus, nitrogen and soil humidity, increased the value of EMI. Thus, it increases the presence of taxa indicating higher soil quality. The ideal value for taxa was $15-50 \mathrm{mg} / \mathrm{kg}$ potassium, $1.3-4.0 \mathrm{mg} / \mathrm{kg}$ phosphorus, $15-50 \mathrm{mg} / \mathrm{kg}$ nitrogen, $6.8-7.0 \mathrm{pH}$ and 35-75\% for moisture.

\section{Discussion}

Bioindicators are useful to highlight changes in complex systems. This is particularly true for environmental soil problems. Environmental indicators represent synthesized information about the state of the environment for management. Ecological indicators have two main functions. First, to decrease the number of measures that would normally be required to represent a situation. Second, to simplify the communication process through which information on collected data is conveyed to final users (Muller et al., 2000; Brygadyrenko, 2015; Porhajašová et al., 2015). Calculation of QBS index does not require estimates of the number of specimens for every group or the single species present in the sample. Compared with methods that use a single taxon as biological indicators, such as ants (Wiezik et al., 2017; Purkart et al., 2019), isopods (Paoletti \& Hassall, 1999) and mites (Maraun \& Scheu, 2000), the QBS index does not require a species level diagnosis, and is therefore considered an appropriate tool for large-scale monitoring, where a large number of samples may be gathered.

Analysis of our results showed significant differences in QBS values between crops. We recorded higher QBS values in fields with grass mixture, Pisum sativum, Triticum aestivum, T. spelta. The QBS values appear to increase as arable land use pressure is reduced. These differences are greater for the intensive crops, such as corn or tomato, and smaller for the low input crops, such as wheat (Triticum) and barley (Hordeum). 


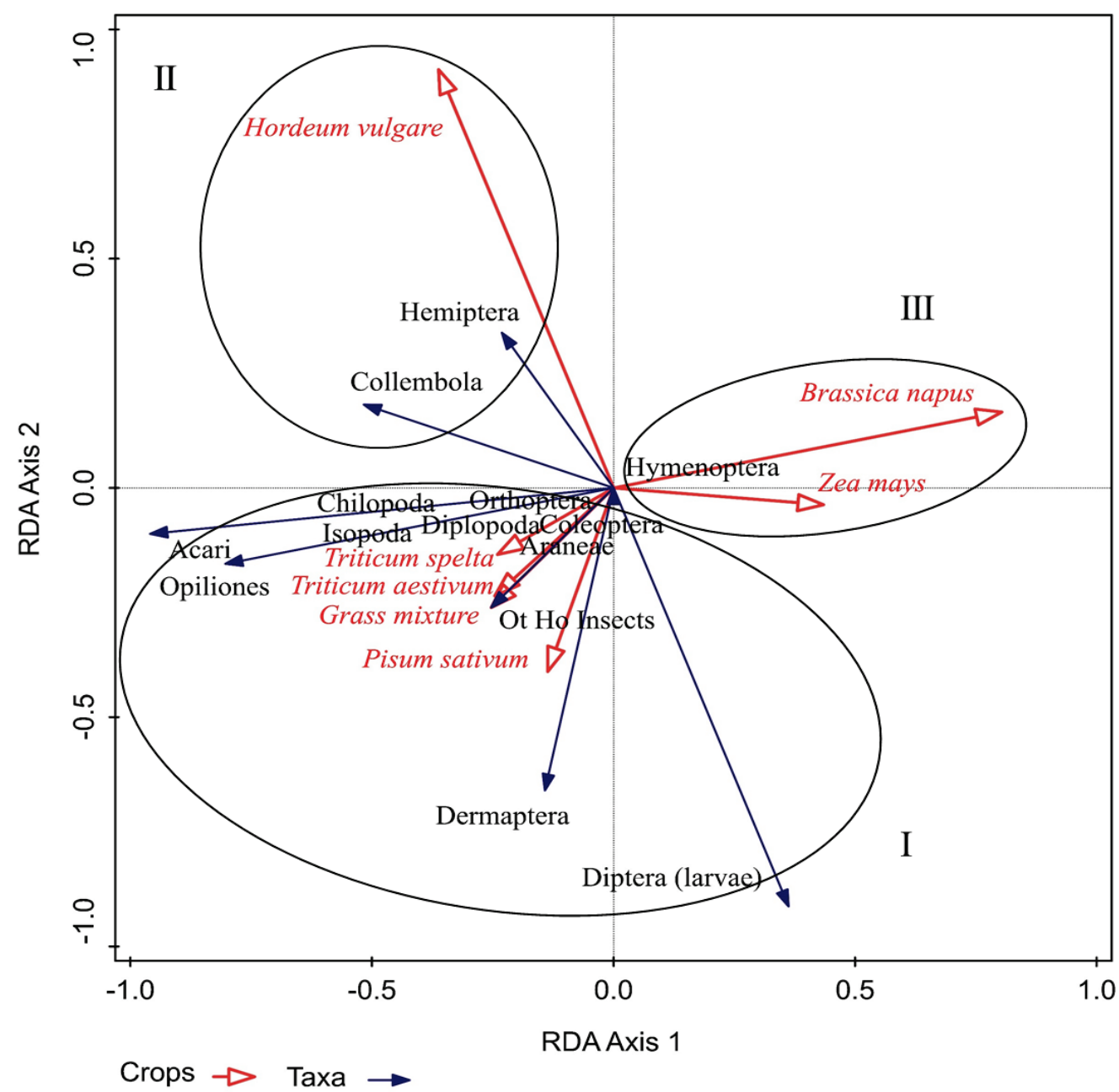

Fig. 2. RDA analysis of soil arthropods with crops

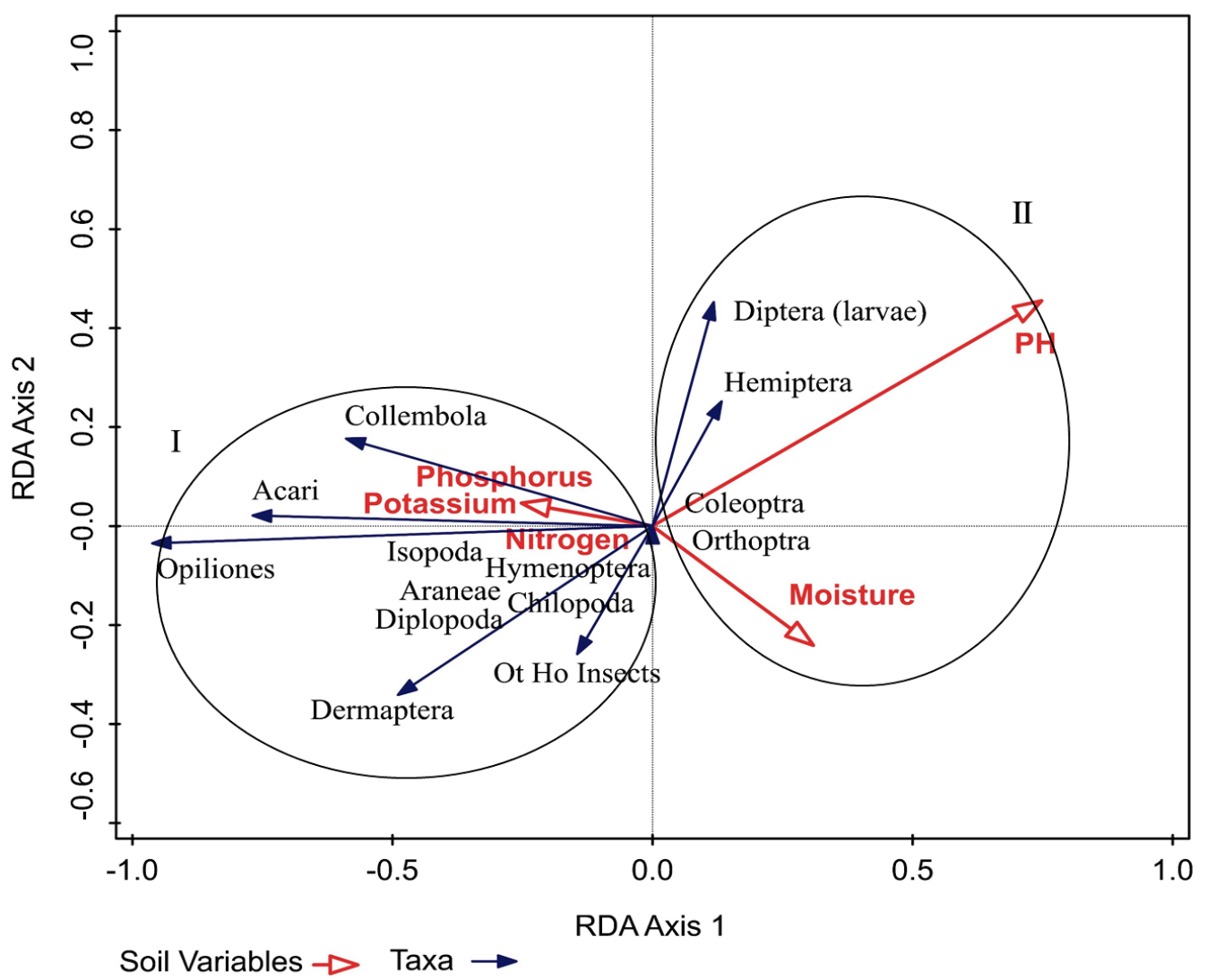

Fig. 3. RDA analysis of soil arthropods with respect to soil variables 

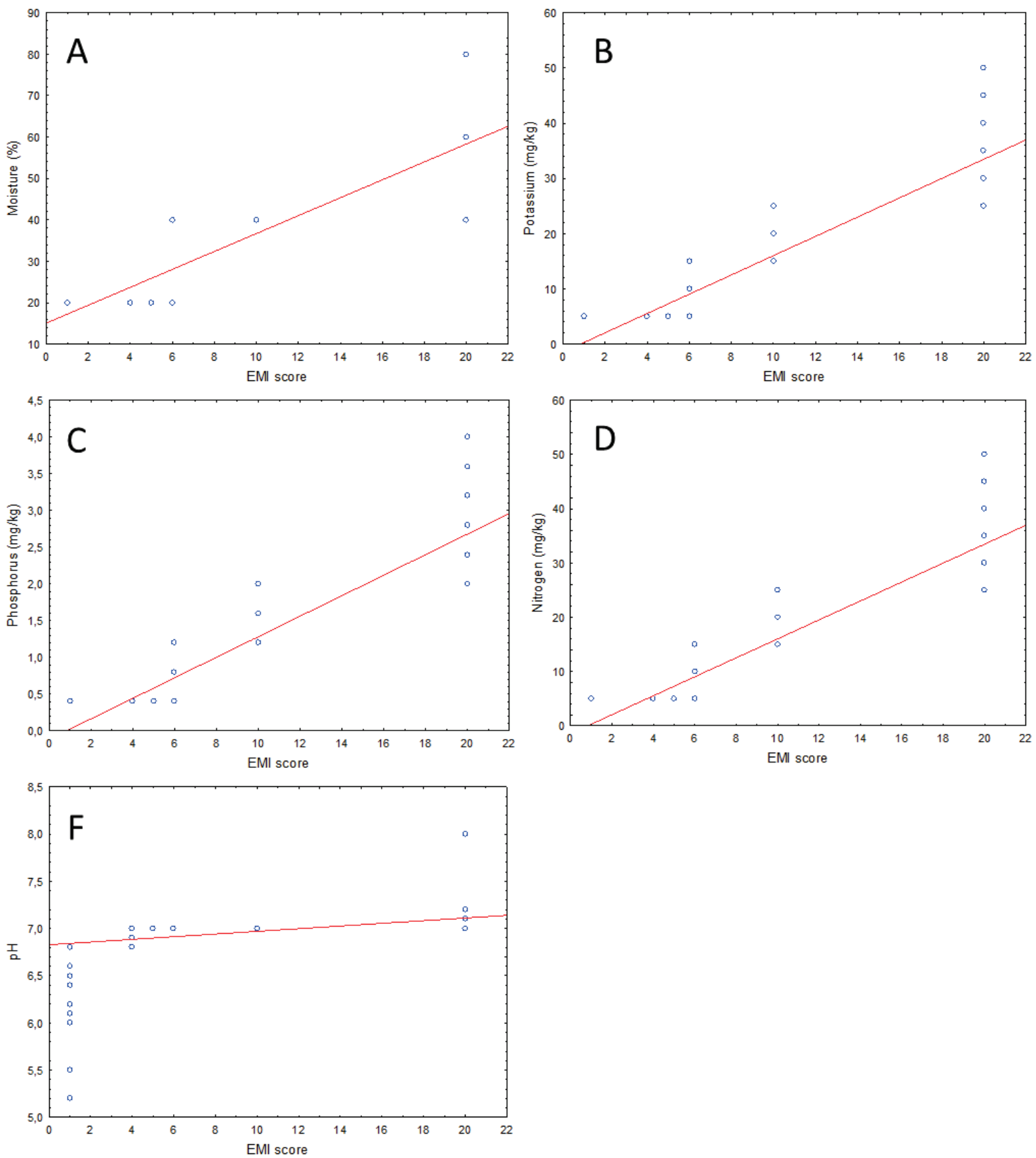

Fig. 4. Linear regression model potassium, phosphorus, nitrogen, $\mathrm{pH}$, moisture on the value EMI

Our results also indicated smaller differences in QBS index values between Hordeum vulgare, Triticum aestivum and T. spelta. Thus, QBS is at present considered a useful tool in the fields of ecological risk assessment, environmental impact studies, as well as an early warning device for soil degradation evaluation, and for that reason may be useful also in areas prone to desertification (Gardi et al., 2003).

The multivariate analysis of our results, of single soil arthropods in relation to land use showed that the predominance of taxa is linked to grass mixture, Pisum sativum, Triticum aestivum, T. spelta. The predominance of soil arthropods in the same crops is noted in (Porhajašová et al., 2018). We also noted the predominance of soil arthropods with phosphorus, nitrogen and potassium binding. Thus, our results agreed with the results of Langellotto \& Denno (2004), who observed a decline in soil arthropods with increasing land use. The response of soil organisms is a key part of the sustainability of the soil ecosystem (Langraf et al., 2020) being considered as a bioindicator of the environment (Krumpálová, 2002; Krumpálová et al., 2009; Bote \& Romero, 2012; Magura et al., 2020). Soil arthropods living in agricultural landscapes have a wider tolerance than the soil arthropods of natural habitats (Lenoir \& Lennartsson, 2010). They also achieve a high local density due to the influence of agriculture (Holecová et al., 2003). We recorded an arthropod community dominated by Coleoptera, Collembola and Diplopoda. The great abundance of these groups influenced the maintenance of the natural balance and substance cycle of the biogenic elements in ecosystems such as carbon, nitrogen, sulfur and phosphorus (Morris \& Campos, 1999). Their activities accelerated the decomposition of plant residues, aerated the soil and improved soil structure and quality (Kotroczó et al., 2020). The presence of other soil arthropods was heterogeneous and may depend on the management regime and the surrounding vegetation (Moço et al., 2010).

Relationships between soil arthropods and chemical parameters have a positive influence on organic matter supply of soil fauna. The $\mathrm{C} / \mathrm{N}$ ratio can be considered as an index of the quality and biodegradation of organic matter. In soils with a higher $\mathrm{C} / \mathrm{N}$ ratio, the fungal contribution to biodegradation tends to prevail and this has a positive effect on soil arthropod communities (Laiho et al., 2001). Diversity of soil arthropods can be cor- 
related to soil $\mathrm{pH}$, potassium, phosphorus and nitrogen (Brygadyrenko, 2015a, 2015b; Alekseev \& Ruchin, 2020). The result has a direct significant and positive effect on soil fauna richness and the presence of taxa indicating higher soil quality (Da Silva et al., 2016). Our results also point to a strong positive relationship between environmental variables (soil $\mathrm{pH}$, potassium, phosphorus, nitrogen and moisture) and EMI values. The results show that as the value of environmental variables increases, so does the EMI value, indicating the presence of soil arthropods occurring in higher quality soils. An absence of positive correlation between soil arthropods and soil chemistry was found (Teofilova, 2021). A negative correlation of $\mathrm{pH}$ with springtails, was recorded by (Fazekašová \& Bobul'ovská, 2012), who identified it as the main soil parameter influencing Collembola communities. Soil arthropods are involved in ecosystems in maintaining the natural balance and material cycle of the biogenic elements such as carbon, nitrogen, sulfur and phosphorus (Brygadyrenko, 2016) and they have more suitable conditions in sustainable agriculture (Saranenko, 2011).

\section{Conclusions}

Our results have provided new knowledge about the soil quality based on the QBS index in the conditions of Brassica napus, Pisum sativum, Triticum aestivum, T. spelta, Zea mays and grass mixture in Central Europe. We confirmed a higher value of the QBS index and also the correlation of more soil arthropods to fields with grass mixture, Pisum sativum, Triticum aestivum, T. spelta. The dispersion of soil arthropods was also positively influenced by soil moisture, $\mathrm{pH}$ of soil, and levels of phosphorus, potassium and nitrogen. The values of the EMI index were positively influenced by soil moisture, $\mathrm{pH}$ soil, phosphorus, potassium and nitrogen. They pointed to an increase in soil arthropods with a higher EMI value and thus to a higher soil quality. Soil arthropods are important drivers of ecosystem functions such as nutrient cycling, pest control and maintenance of soil structure. They are important for increasing biomass, which affects crop yields. Therefore, it is important to promote the strategies for addressing the conservation of soil arthropods in agricultural landscapes.

This research was supported by the grants VEGA 1/0604/20 Environmental assessment of specific habitats in the Danube Plain. KEGA No. 019UKF-4/2021 Creation and innovation of education-Zoology for Ecologists, part-Invertebrates.

The authors declare no conflict of interest.

\section{References}

Alekseev, S. K., \& Ruchin, A. B. (2020). Fauna and abundance of ground beetle (Coleoptera, Carabidae) in pine forests. Entomology and Applied Science Letters, 7(1), 1-9.

Aspetti, G. P., Boccelli, R., Ampollini, D., Del Re, A. A. M., \& Capri, E. (2010). Assessment of soil-quality index based on microarthropods in corn cultivation in Northern Italy. Ecological Indicators, 10(2), 129-135.

Bote, P. J., \& Romero, A. J. (2012). Epigeic soil arthropod abundance under different agricultural land uses. Spanish Journal of Agricultural Research, 10(1), 55-61.

Brygadyrenko, V. V. (2015). Community structure of litter invertebrates of forest belt ecosystems in the Ukrainian steppe zone. International Journal of Environmental Research, 9(4), 1183-1192.

Brygadyrenko, V. V. (2015a). Evaluation of the ecological niche of some abundant species of the subfamily Platyninae (Coleoptera, Carabidae) against the background of eight ecological factors. Folia Oecologica, 42(2), 75-88.

Brygadyrenko, V. V. (2015b). Parameters of ecological niches of Badister, Licinus and Panagaeus (Coleoptera, Carabidae) species measured against eight ecological factors. Baltic Journal of Coleopterology, 15(2), 137-154.

Brygadyrenko, V. V. (2016). Effect of canopy density on litter invertebrate community structure in pine forests. Ekológia (Bratislava), 35(1), 90-102.

Brygadyrenko, V. V., \& Reshetniak, D. Y. (2014). Trophic preferences of Harpalus rufipes (Coleoptera, Carabidae) with regard to seeds of agricultural crops in conditions of laboratory experiment. Baltic Journal of Coleopterology, 14(2), $179-190$.
Coleman, D. C., \& Wall, D. H. (2015). Soil fauna: Occurrence, biodiversity, and roles in ecosystem function. Chapter 5. In: Paul, E. A. (Ed.). Soil microbiology, ecology, and biochemistry. 4th ed. Academic Press, New York. Pp. 111-149.

Da Silva, P. M., Carvalho, F., Dirilgen, T., Stone, D., Cramer, R., Bolger, T., \& Sousa, J. P. (2016). Traits of collembolan life-form indicate land use types and soil properties across an European transect. Applied Soil Ecology, 97, 69-77.

Fazekašová, D., \& Bobul'ovská, L. (2012). Soil organisms as an indicator of quality and environmental stress in the soil ecosystem. Životné Prostredie, 46(2), 103-106.

Gardi, C., Jacomini, C., Menta, C., \& Parisi, V. (2003). Evaluation of land use and crop management impacts on soil quality: Application of QBS methods. In: Francaviglia, R. (Ed.). Agricultural impacts on soil erosion and soil biodiversity: Developing indicators for policy analysis. Proceedings from an OECD Expert Meeting on Soil Erosion and Soil Biodiversity Indicators, Rome.

Gilley, J. E., Doran, J. W., \& Eghball, B. (2001). Tillage and fallow effects on selected soil quality characteristics of former conservation reserve program sites. Journal of Soil and Water Conservation, 56(2), 126-132.

Holecová, M., Lukáš, J., \& Harakal’ová, E. (2003). Mravce (Hymenoptera, Formicidae) dubovo-hrabových lesov v okolí Bratislavy (JZ Slovensko). Folia Faunistica Slovaca, 8, 63-69.

Kotroczó, Z., Juhos, K., Biró, B., Kocsis, T., Pabar, S. A., Varga, C., \& Fekete, I. (2020). Effect of detritus manipulation on different organic matter decompositions in temperate deciduous forest soils. Forests, 11(6), 675.

Krumpálová, Z. (2002). Epigeic spiders (Araneae) of one Middle Danube floodplain forest. Biologia, 57(2), 161-169.

Krumpálová, Z., Krumpál, M., \& Štrbík, I. (2009). Classification of epigeic spiders (Araneae) at the western part of the Carpathians (Slovakia). Biologia, 64(1), $116-123$.

Laiho, R., Silvan, N., Cárcamo, H., \& Vasander, H. (2001). Effects of water level and nutrients on spatial distribution of soil mesofauna in peatlands drained for forestry in Finland. Applied Soil Ecology, 16(1), 1-9.

Lajtha, K., Bowden, R. D., Crow, S., Fekete, I., Kotroczó, Z., Plante, A., Simpson, M. J., \& Nadelhoffer, K. J. (2018). The detrital input and removal treatment (DIRT) network: Insights into soil carbon stabilization. Science of The Total Environment, 640-641, 1112-1120.

Lal, R. (2004). Soil carbon sequestration impacts on global climate change and food security. Science, 304(5677), 1623-1627.

Langellotto, G. A., \& Denno, R. F. (2004). Responses of invertebrate natural enemies to complex-structured habitats: A meta-analytical synthesis. Oecologia, 139, 1-10.

Langraf, V., David, S., Babosová, R., Petrovičová, K., \& Schlarmannová, J. (2020). Change of ellipsoid biovolume (EV) of ground beetles (Coleoptera, Carabidae) along an urban-suburban-rural gradient of Central Slovakia. Diversity, 12(12), 475

Lavelle, P., Decaëns, T., Aubert, M., Barot, S., Blouin, M., Bureau, F., Margerie, P., Mora, P., \& Rossi, J.-P. (2006). Soil invertebrates and ecosystem services. European Journal of Soil Biology, 42(1), S3-S15.

Lenoir, L., \& Lennartsson, T. (2010). Effects of timing of grazing on arthropod communities in semi-natural grasslands. Journal of Insect Science, 10, 60.

Li, Y., Lindstrom, M. J., Zhang, J., \& Yang, J. (2001). Spatial variability of soil erosion and soil quality on hillslopes in the Chinese Loess Plateau. Acta Geologica Hispanica, 35, 261-270.

Magura, T., Ferrante, M. L., \& Lövei, G. L. (2020). Only habitat specialists become smaller with advancing urbanization. Global Ecology and Biogeography, 29, 1978-1987.

Majzlan, O. (2009). Bezchordáty a chordáty. Danubiaprint, a.s., Bratislava.

Maraun, M., \& Scheu, S. (2000). The structure of oribatid mites communities (Acari, Oribatida): Patterns, mechanisms and implications for future research. Ecography, 23(3), 374-382.

Menta, C., \& Remelli, S. (2020). Soil health and arthropods: From complex system to worthwhile investigation. Insects, 11(1), 54.

Menta, C., Leoni, A., Bardini, M., Gardi, C., \& Gatti, F. (2008). Nematode and microarthropod communities: Comparative use of soil quality bioindicators in covered dump and natural soils. Environmental Bioindicators, 3(1), 35-46.

Moço, M. K. S., Gama-Rodrigues, E. F., Gama-Rodrigues, A. C., Machado, R. C. R., \& Baligar, V. C. (2010). Relationships between invertebrate communities, litter quality and soil attributes under different cacao agroforestry systems in the south of Bahia, Brazil. Applied Soil Ecology, 46(3), 347-354.

Morris, T., \& Campos, M. (1999). Predatory insects in olive-grove soil. Zoologica Baetica, 10, 149-160.

Muller, F., Hoffmann-Kroll, R., \& Wiggering, H. (2000). Indicating ecosystem integrity - theoretical concepts and environmental requirements. Ecological Modelling, 130, 13-23.

Murphy, B. W. (2014). Soil organic matter and soil function-review of the literature and underlying data. Department of the Environment, Canberra.

Ondrasek, G., Bakić Begić, H., Zovko, M., Filipović, L., Meriño-Gergichevich, C. Savić, R., \& Rengel, Z. (2019). Biogeochemistry of soil organic matter in agroecosystems and environmental implications. Science of the Total Environment, 658, 1559-1573. 
Orgiazzi, A., Bardgett, R. D., \& Barrios, E. (2016). Global soil biodiversity atlas. European Commission, Publications Office of the European Union, Luxembourg.

Osler, G. H. R., \& Sommerkom, M. (2007). Toward a complete soil C and N cycle: Incorporating the soil fauna. Ecology, 88(7), 1611-1621.

Paoletti, M., \& Hassall, M. (1999). Woodlice (Isopoda: Oniscidea): their potential for assessing sustainability and use as bioindicators. Agriculture, Ecosystems and Environment, 74(1/3), 157-165.

Parisi, V., \& Menta, C. (2008). Microarthropods of the soil: Convergence phenomena and evaluation of soil quality using QBS-ar and QBS-C. Fresenius Environmental Bulletin, 17(8), 1170-1174.

Parisi, V., Menta, C., Gardi, C., Jacomini, C., \& Mozzanica, E. (2005). Microarthropod communities as a tool to assess soil quality and biodiversity: A new approach in Italy. Agriculture, Ecosystems and Environment, 105, 323-333.

Pokorný, V., \& Šifner, F. (2004). Book of Insecta. Paseka, Prague.

Porhajašová, J., Babošová, M., Noskovič, J., \& Ondrišík, P. (2018). Long-term developments and biodiversity in carabid and staphylinid (Coleoptera: Carabidae and Staphylinidae) fauna during the application of organic fertilizers under agroecosystem conditions. Polish Journal Environmental Studies, 27(5), 2229-2235.

Porhajašová, J., Noskovič, J., Rakovská, A., Babošová, M., \& Čeryová, T. (2015). Biodiversity and dynamics of occurence of epigeic groups in different types of farming. Acta Horticulturae et Regiotecturae, 1, 5-10.

Potapov, A. M., Goncharov, A. A., Semenina, E. E., Korotkevich, A. Y., Tsurikov, S. M., Rozanova, O. L., Anichkin, A. E., Zuev, A. G., Samoylova, E. S., Semenyuk, I. I., Yevdokimov, I. V., \& Tiunov, A. V. (2017). Arthropods in the subsoil: Abundance and vertical distribution as related to soil organic matter, microbial biomass and plant roots. European Journal of Soil Biology, 82, 88-97.

Purkart, A., Kollár, J., \& Goffová, K. (2019). Fauna of ants (Hymenoptera: Formicidae) of selected sand habitats in Podunajsko Region. Naturae Tutela, 23(1), $101-111$.
Ruchin, A. B., Egorov, L. V., \& Semishin, G. B. (2018). Fauna of click beetles (Coleoptera: Elateridae) in the interfluve of Rivers Moksha and Sura, Republic of Mordovia, Russia. Biodiversitas, 19(4), 1352-1365.

Ruchin, A. B., Egorov, L. V., Alekseev, S. K., Semishin, G. B., \& Esin, M. N. (2021). Notes on the fauna of beetles (Insecta, Coleoptera) adjacent to the territory of the Mordovia State Nature Reserve. Amurian Zoological Journal, 13(1), $12-35$.

Saranenko, I. (2011). Application experience of agricultural lands productivity improvement methods. Polish Journal of Natural Sciencesthis, 26(4), 285-292.

Schoenholtz, S. H., Van Miegroet, H., \& Burger, J. A. (2000). A review of chemical and physical properties as indicators of forest soil quality: Challenges and opportunities. Forest Ecology and Management, 138, 335-356.

Six, J., Elliott, E. T., \& Paustian, K. (2000). Soil structure and soil organic matter. II. A normalized stability index and the effect of mineralogy. Soil Science Society of America Journal, 64(3), 1042-1049.

Teofilova, T. (2021). The ground beetles (Coleoptera: Carabidae) and their role as bioagents. Forest Science, 2021(Special Issue), 125-142.

Violante, P. (2000). Metodi di analisi chimica del suolo. Franco Angeli Milano, Italy.

Wardle, D. A. (2002). Linking the aboveground and belowground components. Monographs in Population Biology. Princeton University Press, Princeton.

Wiezik, M., Gallay, I., Wieziková, A., Čiliak, M., \& Dovčiak, M. (2017). Spatial structure of traditional land organization allows long-term persistence of large Formica exsecta supercolony in actively managed agricultural landscape. Journal of Insect Conservation, 21, 257-266.

Yeates, G. W. (2003). Nematodes as soil indicators: Functional and biodiversity aspects. Biology and Fertility of Soils, 37, 199-210. 